\title{
The Effects of Two Different Cleaning and Disinfection Programs on Broiler Performance and Microbiological Status of Broiler Houses
}

http://dx.doi.org/10.1590/1516-635x1704575-580

Technical Note

\section{-Author(s)}

\section{Burbarelli MFC \\ Merseguel CEB \\ Ribeiro PAPI \\ Lelis KD \\ Polycarpo GV \\ Carão ACPI \\ Bordin RA" \\ Fernandes AM ${ }^{\prime \prime \prime}$ \\ Souza RLM" \\ Moro MEGII \\ Albuquerque $\mathrm{R}^{\prime}$}

Department of Animal Production and Nutrition - FMVZ/USP - Duque de Caxias Norte Av., 225. 13635-900 Jd. Elite Pirassununga - SP

" Nutrition, Animal Production, Health FATEC-SP Carlos Baratinno Street, $\mathrm{n}^{\circ} 99$ CEP 08773-600 Mogi das Cruzes - SP.

III Faculty of Animal Science and Food Engineering - FZEA-USP Duque de Caxias Norte Av., 225. 13635-900 Jd. Elite Pirassununga - SP

Research funded by FAPESP.

\section{-Mail Address}

Corresponding author e-mail address Maria Fernanda de Castro Burbarelli Faculdade de Medicina Veterinária e Zootecnia da USP - FMVZ VNP Rua Duque de Caxias Norte, 225 13635-900 - Pirassununga - SP Email: mfcb@usp.br

\section{EKeywords}

Poultry, health, biosecurity, disinfectants.

\section{ABSTRACT}

The objective of this study was to investigate the influence of two cleaning and disinfection programs on broiler performance and on the microbiological status of the facilities. This trial was an observational study of comparative character. Two experiments were conducted, with 960 birds each. Both experiments were carried out in a positivepressure broiler house. Broilers were distributed in pens equipped with a bell drinker and a tube feeder each. In the first experiment, new wood shavings were used as litter material, and in the second, reused wood shavings were used. Two treatments with16 replicates of 30 birds each were evaluated. The regular treatment consisted of dry and wet organic matter removal, followed by washing. The European treatment consisted of dry organic matter removal, humidification, washing with water under high pressure, detergent application, rinsing, and application of two combined disinfectants: glutaraldehyde 250g/L + formaldehyde 185g/L; p-chlor-m-cresol $210 \mathrm{~g} / \mathrm{L}$. Biosecurity measures were adopted during daily management tasks to prevent cross contamination between treatments. The effectiveness of the treatments was evaluated by microbiological analysis performed before and after treatment applications, as well as by broiler performance results. Live performance results were similar between both treatments when broilers were reared on new litter. When reused word-shavings were used as litter material, the European treatment promoted better broiler performance. The European treatment was more effective than the regular treatment in reducing total microbial counts in the facilities when reused wood shavings were used as litter material, and positively influenced broiler performance.

\section{INTRODUCTION}

The high population of pathogenic bacteria broiler rearing facilities contributes to reduce bird welfare and increases carcass contamination levels. Poultry products are commonly associated with foodborne disease transmission, which may cause significant and negative economic impacts on the industry as live production and processing costs are increased (Payne et al., 2005).

The intensification of broiler production, associated with stressful environmental conditions and management practices, often does not include effective strategies for the control of environmental pathogens, being responsible for increasing health challenges (Barrios, 2009).

Adequate health programs may benefit broiler growth by improving production efficiency and reducing the incidence of flock contamination (Payne et al., 2005). Among the measures applicable in broiler 
production, cleaning and disinfection of broiler houses and downtime between flocks tend to be extremely effective in reducing environmental contamination and early challenges by infectious agents, improving animal performance (Lauandos \& Lima 2007).

Although the influence of cleaning and disinfection on poultry bird health seems to be obvious, there are few studies on the direct relation between these practices and broiler performance, as well as on the effectiveness of these programs in eliminating microorganisms in broiler facilities. Therefore, studies evaluating the effectiveness of cleaning and disinfection procedures and their influence on broiler performance of these animals are needed.

The aim of this study was to assess the influence of cleaning and disinfection programs on broiler performance of broilers, and to evaluate the efficiency of these programs by the microbiological analysis of facilities and equipment.

\section{MATERIAL AND METHODS}

Two experiments were conducted. In each experiment, 960 one-day-old chicks were reared until 42 days of age. In both experiments, birds were weighed and distributed into 32 pens $(1.70 \mathrm{~m} \times 2.50 \mathrm{~m})$. This trial was an observational study of comparative character of two treatments: regular and European cleaning and disinfection methods.

The study was conducted in a positive-pressure broiler house. Each pen was equipped with a bell drinker and a tube feeder. The evaluated treatments were applied to the facilities and equipment, that is, to the floor, walls, gates, pen screens, curtains, ceiling, floor, drinkers, feeders, and buckets. Each treatment consisted of 16 replicates of 30 birds each. Chick average initial weights were $44.68 \pm 0.31 \mathrm{~g}$ ( $p>0.05)$ and $47.14 \mathrm{~g} \pm 0.23$ ( $p>0.05)$ in the first and second experiment, respectively.

The experimental broiler house was divided into two halves isolated from each other by an intermediate area; each half was allocated to one treatment. The birds were housed after cleaning and disinfection procedures of facilities and equipment. In the first experiment, the floor was covered with new wood-shavings litter. In the second experiment, the wood-shavings litter from the first experiment was reused. Before the second experiment, all the litter was removed from broiler house and stored outside, with no separation between the litters of the different treatments. After the cleaning and disinfection procedures, the resused litter was spread on the house floor.

The regular treatment consisted of simple cleaning and disinfection, and included dry and moist organic matter removal, and facility cleaning with a detergent diluted in water at a concentration of $4 \%$ applied at low pressure, rinsing with water, and letting the environment dry. The European treatment started with cleaning: dry organic matter removal, environment humidification with water under low pressure, washing with water under high pressure, alkaline detergent diluted in water at a concentration of $4 \%$ applied at low pressure and left to act for 20 minutes, rinsing with water under pressure, and letting the environment dry.

The disinfection procedure in the European treatment included the application of a disinfectant, which consisted of a combination of glutaraldehyde at $250 \mathrm{~g} / \mathrm{L}$ and formaldehyde at $185 \mathrm{~g} / \mathrm{L}$ at $0.5 \%$ in water, using a backpack sprayer, with action time of $4 \mathrm{~h}$, and of the application of a disinfectant, consisting of a solution of para-chlor-meta-cresol at $210 \mathrm{~g} / \mathrm{L}$ and diluted at $4 \%$ in water only on the floor and walls up to $0.5 \mathrm{~m}$ tall and left to act for $4 \mathrm{~h}$. The disinfectant action periods and concentrations followed the manufacturers' guidelines. All objects and equipment used in the poultry house were submitted to the same cleaning and disinfecting sequence in each treatment: feeders, drinkers, light bulbs, boots, shovels, transport crates, and buckets.

Biosecurity measures were adopted during the daily management practices. Before entering the poultry house, dedicated boots were worn to access each part of the poultry house submitted to each treatment. Boot feet were immersed before entering the poultry house in a disinfecting solution prepared daily. Drinkers were cleaned daily using a sponge and water for organic matter removal in the regular treatment and using a sponge and peracetic acid solution at $100 \mathrm{~g} / \mathrm{kg}$ and benzyl-(C12-C16) chloro-alkyl-dimethyl ammonia at $80 \mathrm{~g} / \mathrm{kg}$ at $0.5 \%$ in water, and rinsed with water in the European treatment. The floor and the walls of the intermediate part of the house was washed daily with water under high pressure and then disinfected with glutaraldehyde at $250 \mathrm{~g} / \mathrm{L}$ and formaldehyde at $185 \mathrm{~g} / \mathrm{L}$ at0.5\% water, applied using a backpack sprayer. After daily management tasks were completed, boots used 
in each half of the house were washed and disinfected, using the procedures corresponding to each treatment.

In order to evaluate broiler performance in both experiments, all birds were weighed at the beginning and end of each evaluated period (days 1 to 7,1 to 21,1 to 35 , or 1 to 42), as well as feed offer and feed residues. The parameters analyzed were body weight $(B W)$, feed intake (FI), feed conversion ratio (FCR), and livability (L).

In order to evaluate the efficiency of cleaning and disinfecting programs, total microbial count was determined using the methodology proposed by Evancho et al., (2001) before and after the application of treatments. Floor, wall, feeders, drinkers, and curtains were sampled for microbial count. Three samples per treatment were collected from the floor, walls, feeders, and drinkers, and two samples per treatment from the side curtains.

The results were analyzed using the Statistical Analysis System (SAS, 2004) software at 5\% significance level. The statistical assumption of residual normality was evaluated by the Shapiro-Wilk test and of homogeneity of variances by the Hartley test. The results of these analyses did not meet the assumptions mentioned above for total microbial count, and therefore, these data were submitted to the nonparametric test of Kruskal-Wallis. Performance data were subjected to analysis of variance and means compared by F test.

\section{RESULTS AND DISCUSSION}

Before the cleaning and disinfecting procedures in the first experiment, total microbial counts were not different between the poultry house areas to be submitted to the different treatments (Table 1). The lack of significant microbial count differences among the samples collected before treatment application is a desirable result, because it shows the homogeneity of the environment. After the treatments, microbiological results were not different either, except for the curtains, which total microbial count was lower in the European treatment.

The result of zero $\mathrm{CFU} / \mathrm{cm}^{2}$ obtained in the curtains in the European treatment demonstrates that the microbial count remained below detection threshold in these samples. This effect was found only in the curtains and may be due to the fact that they are made of plastic with an even impermeable surface, which may have allowed microorganism removal. Porous materials are more difficult to clean than those with impermeable surfaces, favoring microorganism retention in the adhered organic matter (Rathgeber et al., 2009).

Birds housed in the half of the broiler house submitted to the European treatment in the first experiment presented lower Fl and better FCRin days17 (Table 2), as well as better FCR on day21. The better FCR obtained during the starter phase (days 1-21) of the broilers housed in facilities submitted to the European

Table 1 - Total microbial counts (CFU/ $\left.\mathrm{cm}^{2}\right)$ in the environment and equipment before and after cleaning and disinfection, experiment 1 - new litter.

\begin{tabular}{|c|c|c|c|c|c|}
\hline \multirow{3}{*}{ Sampling site } & \multicolumn{2}{|c|}{ European Treat. } & \multicolumn{2}{|c|}{ Regular Treat. } & \multirow{3}{*}{ Probability } \\
\hline & Mean & Median & Mean & Median & \\
\hline & \multicolumn{4}{|c|}{ Before treatment } & \\
\hline Floor & 21010 & 16550 & 9500 & 700 & 0.164 \\
\hline Wall & 293 & 200 & 373 & 0 & 0.132 \\
\hline Drinkers & 133 & 90 & 1296 & 810 & 0.124 \\
\hline Feeders & 2200 & 1200 & 21966 & 13400 & 0.075 \\
\hline \multirow[t]{2}{*}{ Curtain } & 2650 & 1300 & 4075 & 4320 & 0.117 \\
\hline & \multicolumn{4}{|c|}{ After treatment } & \\
\hline Floor & 1466 & 1070 & 3760 & 1340 & 0.747 \\
\hline Wall & 290 & 110 & 2753 & 1830 & 0.054 \\
\hline Drinkers & 1006 & 850 & 1780 & 500 & 0.808 \\
\hline Feeders & 1506 & 600 & 3686 & 2910 & 0.469 \\
\hline Curtain & 0 & 0 & 2255 & 2090 & 0.013 \\
\hline
\end{tabular}

'Kruskal-Wallis test. 
Table 2 - Performance of broilers housed on new litter and reared in facilities cleaned and disinfected according to the regular and European treatments.

\begin{tabular}{|c|c|c|c|c|}
\hline \multirow{2}{*}{ Variables $^{1}$} & \multicolumn{2}{|c|}{ Accommodation in new bed } & \multirow{2}{*}{$\mathrm{CV}^{3}$} & \multirow{2}{*}{ Probability } \\
\hline & EU Treat. ${ }^{2}$ & ReTreat. $^{2}$ & & \\
\hline \multicolumn{5}{|l|}{ 1-7 days } \\
\hline LW(g) & 150 & 151 & 1.95 & 0.249 \\
\hline $\mathrm{Fl}(\mathrm{g})$ & 114 & 120 & 4.65 & 0.007 \\
\hline FCR & 1.07 & 1.09 & 2.12 & 0.026 \\
\hline $\mathrm{L}(\%)$ & 99.79 & 100.00 & 0.59 & 0.325 \\
\hline \multicolumn{5}{|l|}{$1-21$ days } \\
\hline LW(g) & 773 & 759 & 2.47 & 0.056 \\
\hline $\mathrm{FI}(\mathrm{g})$ & 1056 & 1079 & 3.96 & 0.134 \\
\hline FCR & 1.47 & 1.52 & 2.30 & $<0.001$ \\
\hline $\mathrm{L}(\%)$ & 99.58 & 99.79 & 1.00 & 0.559 \\
\hline \multicolumn{5}{|l|}{$1-35$ days } \\
\hline $\operatorname{LW}(g)$ & 1840 & 1840 & 3.92 & 0.903 \\
\hline $\mathrm{Fl}(\mathrm{g})$ & 3040 & 3050 & 3.53 & 0.779 \\
\hline $\mathrm{FCR}$ & 1.70 & 1.70 & 2.48 & 0.933 \\
\hline L (\%) & 98.75 & 99.79 & 2.51 & 0.245 \\
\hline \multicolumn{5}{|l|}{$1-42$ days } \\
\hline LW (g) & 2420 & 2400 & 3.67 & 0.465 \\
\hline $\mathrm{Fl}(\mathrm{g})$ & 4130 & 4170 & 3.48 & 0.474 \\
\hline FCR & 1.73 & 1.75 & 1.92 & 0.111 \\
\hline $\mathrm{L}(\%)$ & 98.33 & 98.54 & 3.02 & 0.844 \\
\hline
\end{tabular}

'Live weight (LW), feed intake (FI), feed conversion ratio (FCR), livability(L). ${ }^{2}$ EU Treat $=$ European treatment. ReTreat $=$ regular treatment. ${ }^{3} \mathrm{CV}=\mathrm{Coefficient}$ of variation $(\%)$.

treatment maybe explained by the positive influence of the applied cleaning and disinfection procedures, although they significantly reduced microbial counts only in the curtains. The aim of the cleaning and disinfection procedures is to reduce the infection pressure in the environment. When the infection pressure is high, microorganisms may overcome the immune defense mechanisms of the birds, causing cell damage, disease, and worse live performance (Mendes et al., 2004).

In the second experiment, the microbiological analyses performed before the cleaning and disinfection programs were applied showed no differences between treatments (Table 3). The consistency of these results indicates good microbiological uniformity of the facilities before beginning the second experiment.

Table 3 - Total microbial counts $\left(\mathrm{CFU} / \mathrm{cm}^{2}\right)$ in the environment and equipment before and after cleaning and disinfection, experiment 2 - reused litter.

\begin{tabular}{|c|c|c|c|c|c|}
\hline \multirow{3}{*}{ Sampling site } & \multicolumn{2}{|c|}{ European Treat. } & \multicolumn{2}{|c|}{ Regular Treat. } & \multirow{3}{*}{ Probability } \\
\hline & Mean & Median & Mean & Median & \\
\hline & \multicolumn{4}{|c|}{ Before treatment } & \\
\hline Floor & 23266 & 14800 & 27500 & 27500 & 0.789 \\
\hline Wall & 27500 & 27500 & 20446 & 8000 & 0.604 \\
\hline Drinkers & 27500 & 27500 & 27500 & 27500 & 1.000 \\
\hline Feeders & 20796 & 9000 & 23000 & 5000 & 0.844 \\
\hline \multirow[t]{2}{*}{ Curtain } & 27500 & 27500 & 27500 & 27500 & 1.000 \\
\hline & \multicolumn{4}{|c|}{ After treatment } & \\
\hline Floor & 226 & 30 & 20133 & 8700 & 0.003 \\
\hline Wall & 450 & 10 & 19116 & 10300 & 0.003 \\
\hline Drinkers & 243 & 300 & 9410 & 530 & 0.196 \\
\hline Feeders & 890 & 70 & 9923 & 1770 & 0.029 \\
\hline Curtain & 900 & 300 & 27500 & 27500 & 0.018 \\
\hline
\end{tabular}

'Kruskal-Wallis Test. 


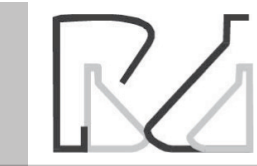

After cleaning and disinfection, the facilities submitted to the European treatment presented lower total microbial counts on the floors, walls, feeders, and curtains (Table 3). These results demonstrate that the European treatment was more effective in reducing the existing bacterial load, thus reducing the environmental infection pressure.

In agreement with the microbiological data, broiler performance was positively influenced by the European treatment. Between days 1-7, the broilers housed in the facilities submitted to the European treatment presented better FCR (Table 4). During the periods of days 1-21, 1-35 and 1-42, the broilers housed in the facilities submitted to the European treatment presented better FCR and higher BW, Fl, and L (Table 4).

The better performance of broilers obtained in the facilities submitted to the European treatment may be related with the lower infection pressure obtained in the effectively clean and disinfected environment. Cleaning and disinfecting programs may improve broiler performance, but this influence is not always quite evident. However, even in such cases, cleaning and disinfection are essential to prevent diseases (Tablante et al., 2002). Ka-Oud et al. (2008) obtained lower mortality rates and higher final weight when evaluating the performance of broilers housed in
The Effects of Two Different Cleaning and Disinfection Programs on Broiler Performance and Microbiological Status of Broiler Houses

facilities submitted to a cleaning and disinfection program.

Another extremely important issue to be considered in cleaning and disinfection studies is related to the environmental challenge. The use of new litter material can act as a physical barrier to microorganisms. Furthermore, new litter material may reduce microorganism proliferation, there by reducing the infection pressure in the broiler rearing environment. When there are no health challenges, little effect is expected with disinfection treatments because, if there are few microorganisms present, the disinfectant will have nowhere to act. Although it was not possible to compare the two experiments, it was observed that the European treatment was very effective in the second experiment, in which reused wood-shavings was used as litter material, supporting the hypothesis that the disinfectant effect depends on the environment where it will be applied.

On the other hand, Jaenisch et al. (2004) emphasized the importance of previous disinfection in broiler houses both with new and reused wood shavings as litter material. Garcia et al. (2010) observed that reused wood-shavings litter requires dirt removal, cleaning, and disinfection of all equipment before placing them inside the poultry house, thereby preventing the additive effect of health challenges.

Table 4 - Performance of broilers housed on reused litter and reared in facilities subjected to cleaning and disinfection according to the regular and European treatments.

\begin{tabular}{|c|c|c|c|c|}
\hline Variable $^{1}$ & EUTreat. $^{2}$ & ReTreat. $^{2}$ & $\mathrm{CV}^{3}$ & Probability \\
\hline \multicolumn{5}{|l|}{ 1-7 days } \\
\hline $\mathrm{LW}(\mathrm{g})$ & 151 & 152 & 2.78 & 0.458 \\
\hline $\mathrm{Fl}(\mathrm{g})$ & 119 & 123 & 5.31 & 0.097 \\
\hline FCR & 1.12 & 1,18 & 3.33 & $<0.001$ \\
\hline $\mathrm{L}(\%)$ & 99.79 & 100.00 & 0.59 & 0.325 \\
\hline \multicolumn{5}{|l|}{$1-21$ days } \\
\hline LW(g) & 753 & 697 & 2.80 & $<0.001$ \\
\hline $\mathrm{Fl}(\mathrm{g})$ & 1041 & 1011 & 2.76 & 0.007 \\
\hline FCR & 1.48 & 1.58 & 2.12 & $<0.001$ \\
\hline $\mathrm{L}(\%)$ & 99.58 & 96.66 & 2.30 & $<0.001$ \\
\hline \multicolumn{5}{|l|}{$1-35$ days } \\
\hline LW (g) & 1750 & 1600 & 5.63 & $<0.001$ \\
\hline $\mathrm{FI}(\mathrm{g})$ & 2850 & 2690 & 3.95 & $<0.001$ \\
\hline FCR & 1.67 & 1.73 & 3.32 & 0.017 \\
\hline $\mathrm{L}(\%)$ & 99.58 & 95.83 & 2.70 & $<0.001$ \\
\hline \multicolumn{5}{|l|}{$1-42$ days } \\
\hline LW(g) & 2340 & 2160 & 4.08 & $<0.001$ \\
\hline $\mathrm{FI}(\mathrm{g})$ & 3910 & 3720 & 3.78 & $<0.001$ \\
\hline FCR & 1.71 & 1.75 & 2.06 & 0.011 \\
\hline L (\%) & 98.89 & 95.21 & 2.94 & $<0.001$ \\
\hline
\end{tabular}

${ }^{1}$ Live weight (LW), feed intake (FI), feed conversion ratio (FCR), livability (L). ${ }^{2} \mathrm{EU}$ Treat $=$ European treatment. Re Treat $=$ regular treatment. ${ }^{3} \mathrm{CV}=$ Coefficient of variation $(\%)$. 
Hooge et al. (2003) support the idea that the reused wood-shavings litter poses a stronger health challenge to the birds, with consequent impairment of broiler performance, compared with new litter. Gifford et al. (1987) suggest the adoption cleaning and disinfection procedures due to increased risk of infectious diseases, which, despite causing low mortality rates, may cause significant performance losses.

\section{CONCLUSION}

The cleaning and disinfection procedures of European treatment are effective in reducing total microbial counts in the facilities and equipment of broiler houses when broilers were reared on reused litter.

The cleaning and disinfection procedures of the European treatment positively influence broiler performance, and these effects are more pronounced when broilers are reared on reused litter.

\section{ACKNOWLEDGMENT}

The authors are grateful to FAPESP for providing the graduate scholarship (2010/04474-9) and for the financial support (2010/18416-0) to carry out this study.

\section{REFERENCES}

Barrios PR. Detecção do vírus da anemia infecciosa das galinhas em minas [tese]. Belo Horizonte: Universidade Federal de Minas Gerais; 2009.

Evancho GM, Sveum, WH, Moberg LJ, Frank JF. Compendium methods for the microbiological examination of foods. 4th ed. lowa: American Public Health Association; 2001.
Garcia RG, Paz ICLA, Caldara FR. Papel da cama na produção e bem estar de frangos de corte [cited 2013 Nov 7]. Campinas: Avisite; 2010. 10 p. Available from: www.avisite.com.br/cet/img/cama_20110309.doc.

Gifford DH, Shane SM, Hugh-Jones M, Weigler BJ. Evaluation of biosecurity in broiler breeders. Avian Diseases 1987;31(2):339-344.

Hooge DM. Natural feed additive containing essential oils and spice extracts enhances broiler performance [cited 2013 Nov 7]. Labège: Feedlnfo Scientific Reviews section; 2003. Available from: www.feedinfo.com.

Jaenisch FRF, Coldebella A, Machado HGP, Abreu PG, Abreu VMN, Santiago V. Importância da higienização na produção avícola [cited 2013 Dec 13]. Concórida; 2004. Available from: www.cnpsa.embrapa.br/sgc/ sgc_publicacoes/cot363.pdf

Ka-Oud HA, Zakia MA, Kamel MM. Evaluation of the immune response in Al vaccinated broiler chickens: effect of biosecurity faults on immune response. International Journal of Poultry Science 2008;7(1):390-396.

Lauandos IP, Lima EA. A importância da desinfecção e do vazio sanitário entre lotes no desempenho do frango [cited 2014 Fev 25]. Campinas: Aveworld; 2007. Available from: http://www.aveworld.com.br/ default. php?acao=documento $\& \operatorname{cod}=110$

Mendes AA, Nass IA, Macari M. Produção de frangos de corte. Campinas: FACTA; 2004

Payne JB, Kroger EC, Watkins SE. Evaluation of disinfectant efficacy when applied to the floor of poultry grow-out facilities. The Journal of Applied Poultry Research 2005;14(1):322-329.

Rathgeber BM, Thompson KL, Ronalds CM, Budgell KL. Microbiological evaluation of poultry house wall materials and industrial cleaning agents. The Journal of Applied Poultry Research 2009;18(3):579-582.

Sas. Sas/Access 9.1 interface to peoplesoft: user's guide. Cary; 2004.

Tablante NL, Myint MS, Johnson YJ, Rhodes K, Colby M, Hohenhaus GA. Survey of biosecurity practices as risk factors affecting broiler performance on the Delmarva Peninsula. Avian Diseases 2002;46(3):730-734

University of Georgia - Agrosecurity. Cleaning and disinfection premises [cited 2014 Jan 20]. Available from: http://www.agrosecurity.uga.edu/ annexes/Annex09 Cleaning.pdf. 